\title{
Aerobic stability of triticale silage in single culture or in mixtures with oat and/or legumes
}

\author{
Valter Harry Bumbieris Junior ${ }^{1}$, Clóves Cabreira Jobim² ${ }^{2}$ Jean-Claude Emile ${ }^{3}$, Juliano \\ Roman $^{4}$, Michele Simili da Silva ${ }^{4}$
}

\footnotetext{
${ }^{1}$ Departamento de Zootecnia da Universidade Estadual de Londrina, Campus Universitário: Rodovia Celso Gracia Cid (PR 445) km 380 CEP: 86051-990, Londrina, Paraná, Brasil.

2 Departamento de Zootecnia da Universidade Estadual de Maringá (UEM). Av. Colombo, 5.790, CEP: 87020-900, Maringá, Paraná, Brasil.

3 Institut National de la Recherche Agronomique (INRA) Unité Expérimentale Fourrages et Environnement (UEFE), Lusignan, France.

4 Programa de Pós-graduação em Zootecnia da Universidade Estadual de Maringá (UEM), CEP: 87020-900, Maringá, Paraná, Brasil.
}

\begin{abstract}
The objective of the present study was to evaluate the aerobic stability and losses during the fermentation process of triticale silages in single crop or in mixtures with oats and/or legumes. The following crops were used for silage production: triticale (X. Triticosecale Wittimack), triticale intercropped with forage pea (Pisum arvense) and triticale intercropped with oats (Avena strigosa Schreb), forage pea and vetch (Vicia sativa). The dry matter content and its recovery did not differ among the silages. Buffer capacity was higher for tricale silage intercropped with oats, forage pea and vetch (88.67 m eq. $\mathrm{NaOH} / 100 \mathrm{~g} \mathrm{DM})$ followed by triticale intercropped with forage pea $(80.80 \mathrm{~m} \mathrm{eq.} \mathrm{NaOH/100} \mathrm{g} \mathrm{DM})$. Electric conductivity values were higher in the intercropped triticale silages. Triticale silage presented the lowest temperatures observed in the silos, and the silages of intercropped triticale silages presented higher heat retention and higher $\mathrm{pH}$ values. Silage of triticale intercropped with oats and legumes presented lower aerobic stability but it did not reduce the aerobic stability of the total feed. Dry matter recovery during storage and in stability evaluations in aerobiosis is similar among the silages.
\end{abstract}

Key Words: aerobic deterioration, forage conservation, silage, total ration

\section{Estabilidade aeróbia de silagens de triticale em cultivo exclusivo ou em misturas com aveia elou leguminosas}

RESUMO - O objetivo neste trabalho foi avaliar a estabilidade aeróbia e as perdas durante o processo de fermentação de silagens de triticale em cultivo exclusivo ou em misturas com aveia e/ou leguminosas. As culturas utilizadas para produção das silagens foram: triticale (X. Triticosecale Wittimack); triticale em consórcio com ervilha-forrageira (Pisum arvense); e triticale em consórcio com aveia (Avena strigosa Schreb), ervilha-forrageira e ervilhaca (Vicia sativa). O teor de matéria seca e a recuperação de matéria seca não diferiram entre as silagens. A capacidade tampão foi maior para a silagem de triticale cultivado em consórcio com aveia, ervilha-forrageira e ervilhaca $(88,67 \mathrm{~m}$ eq. NaOH/100 g de MS), seguida da silagem de triticale cultivado em consórcio com ervilha-forrageira $(80,80 \mathrm{~m}$ eq. $\mathrm{NaOH} / 100 \mathrm{~g}$ de $\mathrm{MS})$. Os valores de condutividade elétrica foram maiores nas silagens de triticale cultivado em consórcio. A silagem de triticale apresentou as menores temperaturas observadas nos silos, e as silagens de triticale cultivado em consórcio, maior retenção de calor e maiores valores de $\mathrm{pH}$. A silagem de triticale em consórcio com aveia e leguminosas apresenta menor estabilidade aeróbia e não reduz a estabilidade aeróbia da ração total. A recuperação de matéria seca durante a armazenagem e na avaliação da estabilidade em aerobiose é semelhante entre as silagens.

Palavras-chave: conservação de forragens, deterioração aeróbia, ração total, silagem

\section{Introduction}

Although ensilage procedure has been known for many centuries, many questions still remain related to silo management after its opening. For example, aerobic deterioration of the silage, a phenomenon that results from air penetration of the silos, is one of the main problems in the silage conservation process. Oxygen can penetrate into the mass even when the silo is closed but especially during the unloading phase and when silage is being given to the animals (Bernardes et al., 2005).

Some authors (Muck et al., 2003; Amaral et al., 2007) have suggested that the high specific mass of ensilaged forage significantly reduces the oxygen present in the material and guarantees anaerobic conditions favorable to the fermentation process. Factors related to the good 
specific mass of the ensilaged material, such as compacting pressure, particle size and dry matter content, were reported by Jobim et al. (2007) as being essential to reduce losses generated by aerobic deterioration of the silage.

According to Pahlow et al. (2003) higher environmental temperatures contribute to the development of deteriorative microorganisms. However, a determining factor for less aerobic deterioration is the correct dimensioning and management of silo unloading, factors that are completely inherent to the use process that can make a great difference in the amount of the total losses at the end of silage use.

When total feed ingredients are included in the silage, alteration in the temperature in aerobic exposure phase is expected because there are higher nutrient contents for the deteriorative microorganisms (Bernardes et al., 2007), but this possible increase in temperature is also correlated with factors intrinsic to the fermentation process, such as exposure time of the silage to the air and environmental temperature.

Thus, the objectives of the present study were to assess the aerobic stability and dry matter recovery of the total feeds and the single triticale silages or in mixtures with oats and/or legumes.

\section{Material and Methods}

The experiment was carried out at INRA - French National Insitute for Agricultural Research, located in Lusignan, Vienne department, France, $42^{\circ} 65^{\prime}$ east and $15^{\circ} 82^{\prime}$ north (Figure 1).

The crops used for silage production were triticale (X. Triticosecale Wittimack), triticale intercropped with forage pea (Pisum arvense) and triticale intercropped with oats (Avena strigosa Schreb), forage pea and vetch (Vicia sativa). Each crop was cultivated in an area of approximately $3 \mathrm{ha}$, and the varieties were Grandval ${ }^{\circledR}$, Fringante ${ }^{\circledR}$, Pepite ${ }^{\circledR}$ and Assas ${ }^{\circledR}$, for the triticale, oats, forage pea and vetch, respectively.

To establish single crop triticale, 220 seeds were used per $\mathrm{m}^{2}$, and for the legumes forage pea and vetch, 20 and 17 seeds per square $\mathrm{m}^{2}$ were used, respectively. In the mixture of the four species, the grasses were sown with 110 seeds per $\mathrm{m}^{2}$. Triticale received $80 \mathrm{~kg} / \mathrm{ha}$ nitrogen fertilizer as ammonia nitrate in a single application, while nitrogen fertilizer was not applied to the other cultivars intercropped with legumes. Agricultural chemicals, other chemical fertilizers and irrigation were not applied to any of the crops.

The crops were planted in the transition from fall to winter 2006 and harvested in the spring in 2007, when the grass grains were at the paste-flour stage. Before harvesting the forage, five $1-\mathrm{m}^{2}$ samples were taken from each one of the crops to assess the appearance frequency of each species. The species were manually separated, weighed and then dried in a chamber at $80^{\circ} \mathrm{C}$ for 48 hours to calculate the frequency of each species.

The silages were stored in bunker-type silos with approximately 60 ton capacity. The forage was harvested with a John Deere ${ }^{\circledR}$ self-propelled silage harvester, model 5730 , with a rotating disc platform. Immediately after loading and compacting, the silos were properly sealed in doublefaced canvas. After 120-day storage, the silos were opened for the assessments and to feed dairy cows.

The particle size of the silages was determined following the modified technique by Melcion (2000) where, with the help of an AS200 digit-Retsch ${ }^{\circledR}$ particle separator, in which a 30 -g sample of dry silage was placed in a chamber at $55^{\circ} \mathrm{C}$ for 72 hours at the top of a stack of seven sieves, placed in decreasing order $(19.0 ; 8.0 ; 4.0 ; 3.6 ; 2.8 ; 1.8$ and $<1.8 \mathrm{~mm})$ and vibrated at $40 \mathrm{~nm}$ intensity for five minutes. The fractions retained in each sieve were weighed to determine the particle distribution. Five replications were carried out for each silage to obtain the frequency of the different particle sizes in the silage.

Temperature was recorded in the silo panels during the animal feeding period to identify the main regions with heating from microbiological activity. Temperatures were measured on the silo panels at three different heights (40, 80 and $120 \mathrm{~cm}$ ) from the soil, and the silo height was $160 \mathrm{~cm}$. Five fixed points were measured at each height and repeated twice a day (at 10 a.m. and 4 p.m.) for 10 consecutive days, from November $26^{\text {th }}$ to December $5^{\text {th }} 2007$, and the silage was removed only once a day ( 8 a.m.). The temperatures were measured with a Checktemp ${ }^{\circledR}$ digital thermometer model 1, at a $10 \mathrm{~cm}$ depth. The obtained data were entered in a Microsoft Office Excel 2007 spreadsheet and then images were produced with a calorimetric scale using Surfer 7.0 software.

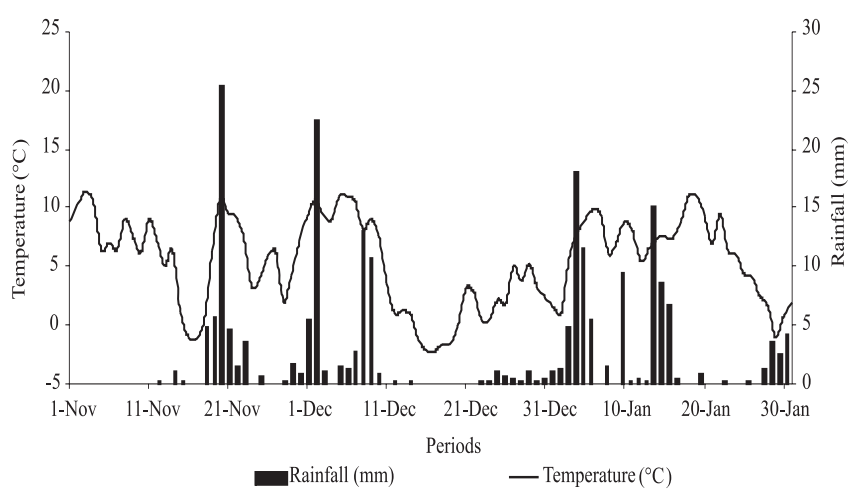

Figure 1 - Temperature and rainfall values during the experimental period (Winter 2007/2008). 
The silage electric conductivity (EC) was measured every 21 days, during use, following methodology by Kraus et al. (1997). The buffer capacity of all the silages was also analyzed according to Playne \& McDonald (1966).

Losses were estimated by using nine fine mesh polyethelene bags containing approximately $5 \mathrm{~kg}$ forage, distributed inside each silo during ensilage. The bags were 3-by-3 placed, on the upper, middle and lower layers of the silos, precisely in the middle of each silo. The bags were removed when the silos were unloaded and they were weighed immediately after removal to calculate the dry matter at recovery, following the equation by Jobim et al. (2007);

$$
R D M b=100-\left[\frac{(G F M e \times D M e)-(G F M r-D M r)}{G F M e \times D M r} \times 100\right]
$$

in which: $\mathrm{RDMb}=$ dry matter recovery in the bags (\%); $\mathrm{GFMe}=$ green forage matter in the bags at ensilage $(\mathrm{kg})$; $\mathrm{DMe}=\mathrm{DM}$ contents of the forage at ensilage $(\%) ; \mathrm{GFMr}=$ green forage matter in the recovered bags $(\mathrm{kg}) ; \mathrm{DMr}=$ forage DM content in the recovered bags (\%).

To determine the specific matter (SM) of the silage from the different heights where the temperatures were measured, a 5-cm diameter, 40-cm long stainless steel cylinder was used, with a serrated cutting edge to cut the silage better. This cylinder was attached to a manual electric drill (Bosch ${ }^{\circledR}$ $7500 \mathrm{~W}$ ) that perforated the panel at the determined points. Each cylinder depth was recorded to later calculate the volume and specific mass of the referred point. Three points were measured for each height in each one of the silos.

Some parameters concerning the fermentation quality of the silage were also analyzed and those with direct or indirect relationship with the DM recovery and stability in aerobiosis. However, these variables will be discussed in a descriptive manner.

As the silages were assigned for lactating cows and were mixed with the concentrate for feeding, a second experiment was carried out to measure the temperatures and $\mathrm{pH}$ values of the silage, total feed and the dry matter recovery after the aerobic exposure period. Plastic boxes were used with 6-kg silage capacity and three replications for each silage. The boxes with the silage were kept in a closed shed, but the environment was not controlled. A second set of boxes was submitted to the same conditions to assess the $\mathrm{pH}$ every day during the period when the temperatures were measured.

The $\mathrm{pH}$ values were obtained according to Cherney \& Cherney (2003), based on the dilution of 15 -g fresh silage in $125 \mathrm{ml}$ distilled water and the $\mathrm{pH}$ was read after 1-hour rest. The total feed was calculated for a 60:40 roughage:concentrate ratio and the Diapason ${ }^{\circledR}$ commercial concentrate that contained $89 \%$ dry matter, $18 \%$ crude protein at $3 \%$ ether extract on the basis of rye, wheat meal, rapeseed cake, byproducts from the manufacture of amino acids, sugar cane molasses, calcium carbonate, sunflower cake, pre-mixture additive and common salt. Proportion of each ingredient in the mix was not informed by the manufacturer. The same quantity of concentrate was used in all the total feeds, simulating the animal supply. The silages were assessed during eight days and the total feeds for three days of exposure to the aerobic environment and the temperatures were measured in the boxes with a Checktemp ${ }^{\circledR}$ digital thermometer model 1, always placed at the center.

The dry matter recovery (RDM) in aerobiosis at the end of eight days of exposure of the silage to the air and three days of exposure of the total feeds to the air was obtained according to the following equation: $\mathrm{RDM}=($ final $\mathrm{FM} \times$ final DM $) /($ initial FM $\times$ initial DM $) * 100$ where: $R D M=$ dry matter recovery index; final $\mathrm{FM}=$ final mass; final $\mathrm{DM}=$ final $\mathrm{DM}$ content; initial FM = initial forage matter; initial DM = initial DM contents.

To obtain the regression equations, a complete randomized design was used with three replication using a split plot arrangement in which the factors of the plots were the silage and the exposure time to the air was the subplot.

A complete randomized design was used in the other statistical analysis (DM contents, buffer capacity, electric conductivity, specific mass and DM recovery). The data were analyzed by the statistical analysis program SAS (2001) using the GLM procedure and the means were compared by Tukey test at $5 \%$ significance.

\section{Results and Discussion}

Dry matter content (DM) and dry matter recovery (RDM) did not differ $(\mathrm{P}>0,05)$ among the assessed silages (Table 1), but the low percentages of recovered DM could be correlated to the low DM contents (mean 23,53\%) of the silages. This occurred because losses due to lixiviation are normally observed when silage DM contents are below $28 \%$ (McDonald et al., 1991), which partially justified these low DM recovery values.

Buffer capacity was greater $(\mathrm{P}<0.05)$ in the triticale silage with oats, forage pea and vetch followed by that with forage pea because of the presence of legumes in these silages (Table 2). Their presence in the silage (27 and 34\%, respectively, in the triticale silage with oats, forage pea and vetch and in the triticale silage with oats - Figure 2) is a determining factor in raising the buffer capacity of the ensilaged material, because legumes normally have higher 
nitrogen fertilizer content and some inorganic ions in their composition compared to grasses. According to McDonald et al. (1991), buffer capacity is established by the combination of organic acids, salts and proteins present in the crops. Lin et al. (1992) reported buffer capacity values in alfalfa silage of around $40 \mathrm{mEq} \mathrm{NaOH} / 100 \mathrm{~g} \mathrm{DM}$, but these silages had DM contents of around $32 \%$, favorable to ensilage and the natural lowering of the buffer capacity of the crop.

The silages of triticale with oats, forage pea and vetch presented the highest electric conductivity values $(\mathrm{P}<0.05)$ because of the greater concentration of soluble substances (pectin) present in the legumes so that there was a greater concentration of free ions with the rupture of the cell wall in the fermentation process or mechanical effect in the act of ensilaging these crops. Castro et al. (2006) presented results of greater cell lyse in pre-dried Tifton 85 grass silage with higher DM contents (55 and 65\% DM) that presented electric conductivity from 1.096 to $1.032 \mu \mathrm{S} / \mathrm{cm}$, but with DM contents of $25 \%$ the values were coherent with those reported in the present study $(871 \mu \mathrm{S} / \mathrm{cm})$ in the triticale silage.

Regarding the particle size (Figure 3), all the silages presented adequate frequency (\% mass) for the silage compacting aspect.

Table 1 - Dry matter content, dry matter recovery, buffer capacity and electric conductivity of silages of single crop triticale or triticale intercropped with oats and legumes

\begin{tabular}{lccrr}
\hline & \multicolumn{4}{c}{ Silages } \\
\cline { 2 - 4 } Variable & $\begin{array}{c}\text { Triticale } \\
\text { single }\end{array}$ & $\begin{array}{c}\text { Triticale }+ \\
\text { forage pea }\end{array}$ & $\begin{array}{c}\text { Triticale }+ \text { oats }+ \\
\text { forage pea }+ \text { vetch }\end{array}$ & Means \\
\hline Dry matter $(\%)$ & 23.20 & 24.17 & 23.23 & 23.53 \\
Dry matter recovery $(\%)$ & 84.60 & 84.76 & 82.57 & 83.98 \\
Buffer capacity (m.eq NaOH/100 g MS) & $71.93 \mathrm{c}$ & $80.80 \mathrm{~b}$ & $88.67 \mathrm{a}$ & 8.31 \\
Electric conductivity $(\mu \mathrm{S} / \mathrm{cm})$ & $669.00 \mathrm{~b}$ & $1,060.33 \mathrm{a}$ & $1,284.00 \mathrm{a}$ & 2.28 \\
\hline
\end{tabular}

Means followed by different letters on the line were statistically different $(\mathrm{P}<0.05)$ by Tukey test; $\mathrm{CV} \%=$ Coefficient of variation.

Table 2 - Specific mass of the silages in the upper $(120 \mathrm{~cm})$, mid $(80 \mathrm{~cm})$ and lower $(40 \mathrm{~cm})$ areas of the silos

\begin{tabular}{|c|c|c|c|c|}
\hline & \multicolumn{4}{|c|}{ Silages } \\
\hline & Triticale single & Triticale + forage pea & Triticale + oats + forage pea + vetch & $\mathrm{CV} \%$ \\
\hline Upper area $\left(\mathrm{kg}\right.$ de $\left.\mathrm{MS} / \mathrm{m}^{3}\right)$ & $81.30 \mathrm{~b}$ & $124.87 \mathrm{ab}$ & $135.27 \mathrm{a}$ & 18.50 \\
\hline Mid area $\left(\mathrm{kg}\right.$ de $\left.\mathrm{MS} / \mathrm{m}^{3}\right)$ & $108.63 \mathrm{~b}$ & $170.58 \mathrm{a}$ & $142.11 \mathrm{ab}$ & 15.63 \\
\hline Lower area $\left(\mathrm{kg}\right.$ de $\left.\mathrm{MS} / \mathrm{m}^{3}\right)$ & $111.25 b$ & $187.62 \mathrm{a}$ & $169.32 \mathrm{ab}$ & 15.58 \\
\hline Means & 100.40 & 161.02 & 148.90 & - \\
\hline
\end{tabular}

Means followed by different letters on the line are statistically different $(\mathrm{P}<0.05)$ by the Tukey's test.

$\mathrm{CV} \%=$ Coefficient of variation

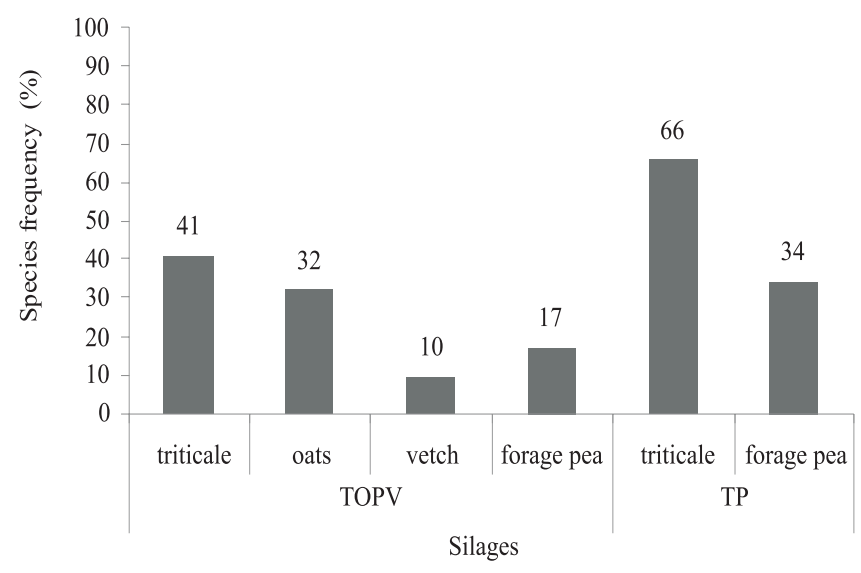

TOPV $=$ Silage of triticale, oats, forage pea and vetch; TP = silage of triticale and forage pea.

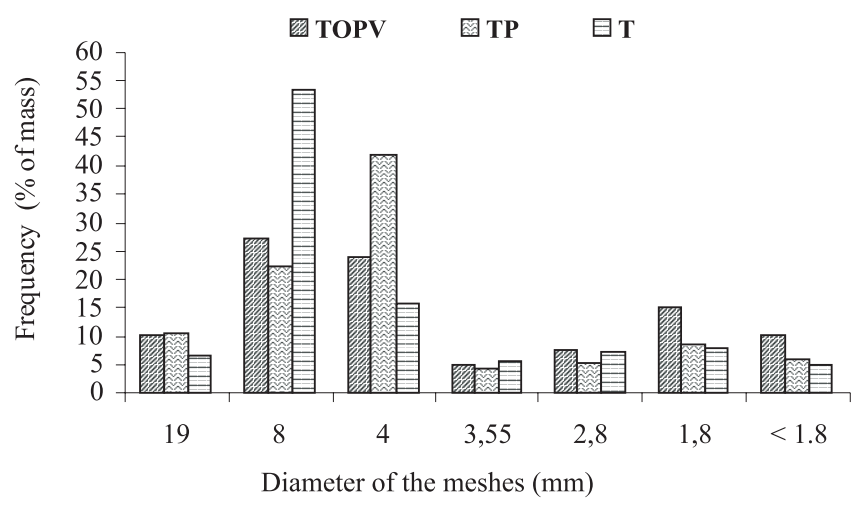

$\mathrm{TOPV}=$ Silage of triticale, oats, forage pea and vetch; $\mathrm{TP}=$ Silage of triticale and forage pea; $\mathrm{T}=$ Triticale silage.

Figure 3 - Silage particle size frequency.

Figure 2 - Species frequency at ensilage. 
However, single crop triticale silage presented greatest frequency in the 8 -mm diameter mesh $(53.3 \%)$ and in the 4-mm mesh diameter the triticale with forage pea presented the greatest frequency compared to the other silages (42\%). The frequency among the silages in the other meshes was similar and there was no discrepancy among them.

Triticale silage with oats and legume presented the highest specific mass values $(\mathrm{P}<0.05)$ in the upper area of the silo followed by the triticale silage with forage pea silage, which presented similar values to the single crop triticale silage, in spite of the high coefficient of variation (Table 2). This was probably because of the larger particle sizes observed in these silages that contributed negatively to the smaller specific mass in the upper area of the silos which is justified because the particle size and the DM content of the material are important factors in obtaining proper compacting for the process of forage conservation.

In the mid and lower areas of the silos, the triticale with forage pea presented the highest specific mass $(\mathrm{P}<0.05)$, followed by the triticale silage with oats and legumes, which was similar to the single crop triticale silage. These results were observed because of the low DM content presented by the crops at the time of cutting. However, the climatic conditions at that moment prevented waiting for the greater maturity stage of the crops.

The results of this study were lower than those recommended by Holmes \& Muck (1999) who estimated specific mass around $225 \mathrm{~kg} / \mathrm{m}^{3}$ for satisfactory quality silage.

The single triticale crop silage presented low temperatures in the upper area of the silos probably because of the smaller specific mass that gave greater porosity and conferred greater susceptibility to temperature exchanges with the external environment. However, the lower lactic acid production and greater acetic and propyonic acid production (Table 3) may have given greater resistance to the deteriorative microorganism action.

According to Muck \& Kung Jr. (1997) and Magalhães \& Rodrigues (2004), the increase in acids such as acetic, propyonic and butyric, could increase the silage aerobic stability because they inhibit its deteriorative microorganisms. The temperatures were higher in the mid and lower parts of the silos, possibly because of the greater heat retention in the mass or even because of the greater microbiological activity in these areas (Figure 4).

The intercropped triticale silage preformed contrary to that of the single crop triticale silage. These silages conserved part of the heat generated in fermentation because of their greater specific mass, so that the triticale silage with forage pea presented irregularly distributed mild temperatures that were above the mean environmental temperature that was $7.5^{\circ} \mathrm{C}$ in the period assessed.

The silage of triticale with oats, forage pea and vetch presented the highest temperatures in the most porous parts of the silage, with temperatures from 19 to $21^{\circ} \mathrm{C}$ in the greatest areas of the silos and showed less stability compared to the other silages. Coincidentally, the triticale silage with oats, forage pea and vetch presented the greatest $(\mathrm{P}<0.05)$ buffer capacity and electric conductivity compared to

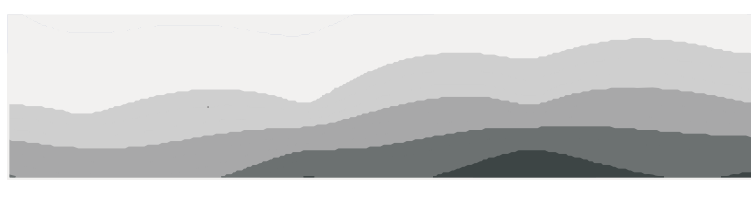

$\mathrm{T}$

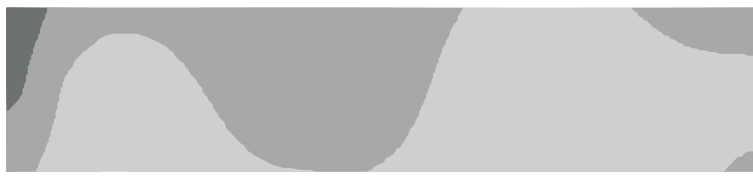

TP

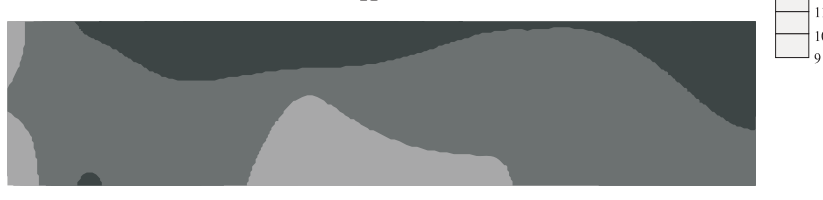

TOPV

$\mathrm{TOPV}=$ Silage of triticale, oats, forage pea and vetch; $\mathrm{TP}=$ Silage of triticale and forage pea; $\mathrm{T}=$ Triticale silage.

Figure 4 - Thermographs on the silo panels during silage use.

Table 3 - Organic acid concentration in silages of single crop triticale or triticale in mixtures with oats and/or legumes

\begin{tabular}{lccc}
\hline Organic acids & \multicolumn{2}{c}{ Silages } \\
\cline { 2 - 4 } & Triticale single & Triticale + forage pea & Triticale + oats + forage pea + vetch \\
\hline Lactic acid $(\mathrm{L}+\mathrm{D})(\mathrm{g} / \mathrm{kg}$ of $\mathrm{DM})$ & 51.40 & 82.40 & 72.80 \\
Acetic acid $(\mathrm{g} / \mathrm{kg}$ of $\mathrm{DM})$ & 49.18 & 27.90 & 46.98 \\
Propyonic acid $(\mathrm{g} / \mathrm{kg}$ of $\mathrm{DM})$ & 4.23 & 1.33 & 1.32 \\
Isobutyric acid $(\mathrm{g} / \mathrm{kg}$ of $\mathrm{DM})$ & $<0.50$ & 0.47 & $<0.50$ \\
$\mathrm{~N}-$ butyric acid $(\mathrm{g} / \mathrm{kg}$ of $\mathrm{DM})$ & $<0.50$ & 0.76 & $<0.50$ \\
Isovaleric acid $(\mathrm{g} / \mathrm{kg}$ of $\mathrm{DM})$ & $<0.50$ & $<0.50$ & $<0.50$ \\
$\mathrm{~N}$-valeric acid $(\mathrm{g} / \mathrm{kg}$ of $\mathrm{DM})$ & $<0.50$ & $<0.50$ & $<0.50$ \\
\hline
\end{tabular}


the other silages, in addition to presenting a considerable quantity of substrate (lactic acid) to be deteriorated $(72.8 \mathrm{~g} / \mathrm{kg}$ DM) compared to the single crop triticale silage $(51.4 \mathrm{~g} / \mathrm{kg}$ DM). This suggested that these silage fermentation quality factors may be negatively correlated to greater temperature accumulation in this silage.

Although the temperatures observed in the silages were higher than the environmental temperature (Figure 2), it was not considered values that could cause significant alterations in the silage quality resulting from temperature raising inside the silos. According to Kung Jr. (2008), temperature is not an absolute indicator of deterioration in silage, because in large silos there is frequently great heat retention even during the winter. The same author reported signs of aerobic deterioration and included temperature measurements higher than 40 to $48^{\circ} \mathrm{C}$ on the silo panel, visible presence of fungi and/or odor characteristic of deteriorated material, in addition to, when possible, the $\mathrm{pH}$ monitoring along with the other variables to check the results.

The silages presented positive linear equations $(\mathrm{P}<0.05)$ in the $\mathrm{pH}$ during the time of exposure to the air (Table 4 ). The equations were quadratic for aerobic stability and in spite of the high coefficient of variation, the coefficients of determination $\left(\mathrm{R}^{2}\right)$ were considered adequate to validate the results.

In the total feeds (Table 5), the regression equations for $\mathrm{pH}$ were positive linear $(\mathrm{P}<0.05)$ in the feeds containing the silages of single crop triticale and triticale with forage pea and quadratic for the silage with oats and legumes, but with a greater $\mathrm{P}$ value $(\mathrm{P}>0.22)$ than that established as the significance parameter in the present study. In spite of the low coefficient of variation observed, possible variations during the data collection period may have interfered in the final results in this silage.

The total feeds containing the silages of single crop triticale and triticale with oats and legumes presented quadratic equations $(\mathrm{P}<0.05)$ in the temperature values during the aerobic stability assessments, and the total feeds containing triticale silage with forage pea presented positive linear equation $(\mathrm{P}<0.05)$. The total feed showed less variation $\left(>R^{2}\right)$ compared to the silage, which might have occurred because of the increase in the dry matter contents of the material exposed to the environment (Table 6).

Although this material was high in substrate for bacteria and other deteriorative microorganisms, the environmental temperature in the assessment period was low which may have partly inhibited the action of these agents.

According to Pahlow et al. (2003), higher environmental temperatures collaborate to develop deteriorative microorganisms. Problems of aerobic deterioration are usually greater in the summer months (Kung Jr., 2008) precisely because of the increase in the environmental temperature.

The triticale silage with oats and legumes presented a maximum temperature peak prior to the other silages and also had the highest maximum temperature that indicated less aerobic stability (Table 5). The triticale silage with forage pea and the silage with oats and legumes presented higher $\mathrm{pH}$ values compared to the single crop triticale silage, a fact that could be attributed to the greater lactic acid intake by deteriorative microorganisms that interfered in the maintenance of the $\mathrm{pH}$ values.

There was no difference $(\mathrm{P}>0.05)$ in the DM recovery of the silage but there was a tendency to greater recovery in the triticale silage with oats and legumes. Bernardes et al. (2007) and Amaral et al. (2008) worked with silage of Brachiaria brizantha cv. Marandu and reported similar mean DM recovery values to those observed in the present study.

The total feeds were stable and did not abruptly alter the temperature or $\mathrm{pH}$ values during the assessment period. However, the DM recovery was inferior to those observed in the silages. It was inferred from this performance that there were DM losses in the total feeds and that the $\mathrm{pH}$ and temperature variables were not efficient to show the deteriorative microorganism activity.

Bernardes et al. (2007) worked with Brachiaria brizantha cv. Marandu silage with similar DM contents

Table 4 - Regression equations for $\mathrm{pH}$ values and temperature during the time of aerobic exposure of the silage

\begin{tabular}{|c|c|c|c|c|}
\hline Silages & Regression & $\mathrm{R}^{2}$ & $\mathrm{P}<\mathrm{F}$ & $\mathrm{CV} \%$ \\
\hline \multicolumn{5}{|c|}{$\mathrm{pH}$} \\
\hline Triticale single & $Y=3.94+0.046 x$ & 0.27 & $* *$ & 5.46 \\
\hline Triticale + oats + forage pea + vetch & $Y=4.36+0.68 x$ & 0.85 & $* *$ & 12.44 \\
\hline \multicolumn{5}{|c|}{ Temperature } \\
\hline Triticale single & $Y=17.63+4.37 x-0.54 x^{2}$ & 0.32 & $* *$ & 26.32 \\
\hline
\end{tabular}

$* * \mathrm{P}<0.05 . \mathrm{CV} \%=$ Coefficient of variation 
Table 5 - Regression equations for $\mathrm{pH}$ values and temperature during the time of aerobic exposure of the total feeds

\begin{tabular}{|c|c|c|c|c|}
\hline Silages & Regression & $\mathrm{R}^{2}$ & $\mathrm{P}<\mathrm{F}$ & $\mathrm{CV} \%$ \\
\hline Triticale single & $\mathrm{Y}=4.32+0.14 \mathrm{x}$ & 0.65 & $* *$ & 2.91 \\
\hline \multirow[t]{2}{*}{ Triticale + oats + forage pea + vetch } & $Y=4.16+0.052 x+0.06 x^{2}$ & 0.54 & 0.22 & 3.49 \\
\hline & \multicolumn{4}{|c|}{ Temperature } \\
\hline Triticale single & $\mathrm{Y}=7.12-1.38 \mathrm{x}+0.65 \mathrm{x}^{2}$ & 0.70 & ** & 9.22 \\
\hline
\end{tabular}

$* * \mathrm{P}<0,05 . \mathrm{CV} \%=$ Coefficient of variation

Table 6 - pH, mean environmental temperature, temperature and DM recovery associated to aerobic stability of the silages and the total feeds

\begin{tabular}{|c|c|c|c|c|c|c|c|c|}
\hline & $\begin{array}{l}\text { Triticale } \\
\text { single }\end{array}$ & $\begin{array}{l}\text { Triticale }+ \\
\text { forage pea }\end{array}$ & $\begin{array}{l}\text { Triticale }+ \text { oats }+ \\
\text { Forage pea }+ \text { vetch }\end{array}$ & $\mathrm{CV} \%$ & $\begin{array}{c}\text { Triticale } \\
\text { single }\end{array}$ & $\begin{array}{l}\text { Triticale }+ \\
\text { Forage pea }\end{array}$ & $\begin{array}{l}\text { Triticale }+ \text { oats }+ \\
\text { Forage pea }+ \text { vetch }\end{array}$ & $\mathrm{CV} \%$ \\
\hline & \multicolumn{4}{|c|}{ Silages } & \multicolumn{4}{|c|}{ Total feeds } \\
\hline Mean temperature $\left({ }^{\circ} \mathrm{C}\right)$ & 22.20 & 20.23 & 21.43 & - & 7.32 & 6.76 & 7.31 & - \\
\hline Maximum temperature $\left({ }^{\circ} \mathrm{C}\right)$ & 27.77 & 23.40 & 37.63 & - & 8.75 & 8.97 & 8.77 & - \\
\hline $\mathrm{N}^{\mathrm{o}}$ days maximum temperature & 4.00 & 4.00 & 2.00 & - & 3.00 & 3.00 & 3.00 & - \\
\hline Number days maximal $\mathrm{pH}$ & 8.00 & 8.00 & 8.00 & - & 2.00 & 3.00 & 2.00 & - \\
\hline Days of aerobic exposition & 8.00 & 8.00 & 8.00 & - & 3.00 & 3.00 & 3.00 & - \\
\hline Dry matter recovery $(\%)$ & $91.76 \mathrm{a}$ & $84.30 \mathrm{a}$ & $94.16 \mathrm{a}$ & 4.70 & $81.24 \mathrm{~b}$ & $81.61 \mathrm{~b}$ & $88.29 \mathrm{a}$ & 2.38 \\
\hline
\end{tabular}

Means followed by different letters on the line are statistically different $(\mathrm{P}<0.05)$ by Tukey test.

$\mathrm{CV} \%=$ Coefficient of variation

and reported values higher than those in the present study $(93,2 \%)$ for DM recovery in the total feed. Similarly, Zanine et al. (2006) worked with inclusion levels of wheat meal in Mombaça grass silages and also observed greater DM recovery ( 97 to $98 \%$ ) than the reported in the present study at the levels of 20 to $60 \%$ wheat meal inclusion.

\section{Conclusions}

The triticale silage with oats and legumes presents less aerobic stability but it does not reduce the aerobic stability of the total feed. The dry matter recovery during storage and in the assessment of stability in aerobiosis is similar among the silages assessed. Dry matter recovery of the total feed is low in all the silages assessed, but the total feeds containing silage of triticale with oats and legumes present the best results.

\section{References}

AMARAL, R.C.; BERNARDES, T.F.; SIQUEIRA, G.R. et al. Características fermentativas e químicas de silagens de capimmarandu produzidas com quatro pressões de compactação. Revista Brasileira de Zootecnia, v.36, n.3, p.532-539, 2007. AMARAL, R.C.; BERNARDES, T.F.; SIQUEIRA, G.R. et al. Estabilidade aeróbia de silagens do capim-marandu submetidas a diferentes intensidades de compactação na ensilagem. Revista Brasileira de Zootecnia, v.37, n.6, p.977-983, 2008.

BERNARDES, T.F.; SIQUEIRA, G.R.; REIS, R.A. Importância do planejamento na produção e uso da silagem. In: EVANGELISTA, A.R.; AMARAL, P.N.C.; PADOVANI, R.F. (Eds.). Forragicultura e pastagens: temas em evidência. 5.ed. Lavras: Universidade Federal de Lavras, 2005. p.121-176.

BERNARDES, T.F.; REIS, R.A.; SIQUEIRA, G.R. et al. Estabilidade aeróbia da ração total e de silagens de capim-marandu tratadas com aditivos químicos e bacterianos. Revista Brasileira de Zootecnia, v.36, n.4, p.754-762, 2007.

CASTRO, F.G.F.; NUSSIO, L.G.; HADDAD, C.M. et al. Perfil microbiológico, parâmetros físicos e estabilidade aeróbia de silagens de capim-tifton 85 (Cynodon sp.) confeccionadas com distintas concentrações de matéria seca e aplicação de aditivos Revista Brasileira de Zootecnia, v.35, n.2, p.358-371, 2006.

CHERNEY, J.H.; CHERNEY, D.J.R. Assering silage quality. In: BUXTON, D.R.; MUCK. R.E.; HARRISON, J.H. (Eds.). Silage Science and technology. Madison: American Society of Agronomy, Crop Science Society of America, Soil Science of America, 2003. p.141-198.

HOLMES, B.J.; MUCK, R.E. Factors affecting bunker silos densities. Madison: University of Wisconsin, 1999. 7p.

JOBIM, C.C.; NUSSIO, L.G.; REIS, R.A. et al. Avanços metodológicos na avaliação da qualidade da forragem conservada. Revista Brasileira de Zootecnia, v.36, p.101-119, 2007 (supl. especial).

KRAUS, T.J.; KOEGEL, R.G.; STRAUB, R.J. et al. Leachate conductivity as an índex for quantifying level of forage conditioning. In: ASAE ANNUAL INTERNATIONAL MEETING, 1997, Minneapolis. Proceedings... Minneapolis: ASAE, 1997. p.1-12.

KUN JR., L. Aerobic stability of silages. In: SIMPÓSIO SOBRE MANEJO ESTRATÉGICO DA PASTAGEM, 4., 2008, Viçosa, MG. Anais... Viçosa, MG: [s.n.], 2008. p.233-248. 
LIN, C.; BOLSEN, K.K.; BRENT, B.E. et al. Epiphytic microflora on alfalfa and whole-plant corn. Journal Dairy Science, v.75, p.2484-249, 1992.

MAGAlHÃeS, V.J.A.; RODRIGUES, P.H.M. Avaliação de inoculante microbiano na composição bromatológica, fermentação e estabilidade aeróbia da silagem pré-seca de alfafa. Revista Brasileira de Zootecnia, v.33, n.1, p.51-59, 2004.

McDonAld, P.J.; Henderson, A.R.; HeRON, S.J.E. The biochemistry of silage. 2.ed. Mallow: Chalcombe Publications, 1991. 340p.

MELCION, J.P. La granulométrie de l'aliment: principe, mesure et obtention. INRA Production Animalles, v.13, n.2, p.81-97, 2000 .

MUCK, R.E.; KUNG JR., L. Effects of silage additives on ensiling. In: SILAGE: FIELD TO FEEDBUNK NORTH AMERICA CONFERENCE, 1997, Hershey. Proceedings... Hershey: NRAES, 1997. p.187-199.
MUCK, R.E.; MOSER, L.E.; PITT, R.E. Postharvest factors affecting ensiling. In: BUXTON, D.R.; MUCK, R.E.; HARRISON, J.H. (Eds). Silage science and technology. Madison: American Society of Agronomy, 2003. p. 251-304.

PAHLOW, G.; MUCK, R.E.; DRIEHUIS, F. et al. Microbiology of ensiling. In: BUXTON, D.R.; MUCK, R.E.; HARRISON, J.H. (Eds.) Silage science and technology. 1.ed. Madison: American Society of Agronomy, 2003. p.31-94.

PLAYNE, M.J.; McDONALD, P. The buffering constituents of herbage and of silage. Journal of the Science of Food and Agriculture, v.17, p.264-268, 1966.

STATISTICAL ANALYSES SYSTEM - SAS. System for Microsoft Windows: Release 8.01. Cary: SAS Institute Inc., 2001. (CD-ROM).

ZANINE, A.M.; SANTOS, E.M.; FERREIRA, D.J. et al. Efeito do farelo de trigo sobre as perdas, recuperação da matéria seca e composição bromatológica de silagem de capim-mombaça. Brazilian Journal of veterinary Research and animal Science, v.43, n.6, p.803-809, 2006. 